\title{
Low Levels of Tissue Factor Are Compatible with Development and Hemostasis in Mice
}

\author{
Graham C.N. Parry, ${ }^{\star}$ Jonathan H. Erlich, ${ }^{*}$ Peter Carmeliet, ${ }^{\ddagger}$ Thomas Luther, ${ }^{\S}$ and Nigel Mackman* \\ $*$ Departments of Immunology and Vascular Biology, The Scripps Research Institute, La Jolla, California 92037; ${ }^{\ddagger}$ Center for Transgene \\ Technology and Gene Therapy, Interuniversity Institute for Biotechnology, Leuven, Belgium; and ${ }^{\S}$ Institute of Pathology, Technical \\ University Dresden, Dresden, Germany
}

\begin{abstract}
Tissue factor (TF) expression is associated with life-threatening thrombosis in a variety of human diseases, including sepsis, cancer, and atherosclerosis. Recently, it was shown that inactivation of the murine TF (mTF) gene results in embryonic lethality. To date, despite extensive studies on the regulation of the TF promoter in vitro, no studies have examined the cis-acting regulatory elements that control TF gene expression in vivo. Here we report that a human TF (hTF) minigene containing the human TF promoter and human TF cDNA directed a low level ( $\sim 1 \%$ relative to mouse TF) of both constitutive and LPS-inducible human TF expression in transgenic mice. Importantly, the human TF minigene rescued the embryonic lethality of murine TF null embryos, suggesting that human TF substituted for murine TF during embryogenesis. Rescued mice $\left(\mathrm{mTF}^{-/-}, \mathrm{hTF}^{+}\right)$, which expressed low levels $(\sim 1 \%)$ of TF activity, developed normally with no signs of a bleeding diathesis, suggesting that low TF expression can maintain hemostasis compatible with normal survival. These studies establish a novel mouse model system that can be used to examine the regulation of the human TF gene in vivo and the impact of low TF levels on the hemostatic balance in various thrombotic diseases. (J. Clin. Invest. 1998. 101:560-569.) Key words: blood coagulation factors $\bullet$ gene expression $\bullet$ regulation $\bullet$ transgenic animals
\end{abstract}

\section{Introduction}

Tissue factor $(\mathrm{TF})^{1}$ is the primary cellular initiator of blood coagulation $(1,2)$. Recent studies indicate that TF plays a role in

Part of this work was presented at the 69th Scientific Session of the American Heart Association in New Orleans, 10-13 November 1996 (1996. Circulation. 94:4059a) and the XVIth Congress of the International Society on Thrombosis and Haemostasis in Florence, Italy, 6-12 June 1997 (1997. Thromb. Haemost. 2427a).

Address correspondence to Nigel Mackman, The Scripps Research Institute IMM-17, 10550 North Torrey Pines Rd., La Jolla, CA 92037. Phone: 619-784-8594; FAX: 619-784-8480; E-mail: nmackman @scripps.edu

Received for publication 5 June 1997 and accepted in revised form 24 November 1997.

1. Abbreviations used in this paper: EMSA, electrophoretic mobility shift assay; G3PDH, glyceraldehyde 3-phosphate dehydrogenase; hTF, human TF; mTF, murine TF; PECs, peritoneal exudate cells; $\mathrm{TF}$, tissue factor; TPCK, $N^{\alpha}$-tosylphenylalanyl chloromethyl ketone.

J. Clin. Invest.

(C) The American Society for Clinical Investigation, Inc. 0021-9738/98/02/0560/10 \$2.00

Volume 101, Number 3, February 1998, 560-569

http://www.jci.org embryogenesis, metastasis, and tumor-associated angiogenesis (3-8). TF is expressed during the early stages of both human and murine embryogenesis and targeted disruption of the murine TF (mTF) gene results in embryonic lethality between days E9.5 and 10.5 (8-11). TF null embryos exhibit abnormal yolk sac vasculature, suggesting that TF may play a role in blood vessel development (11). These studies may explain why there are no reports of humans lacking TF.

$\mathrm{TF}$ is constitutively expressed by perivascular and epithelial cells and plays a key role in hemostasis $(12,13)$. However, inducible expression of TF in a variety of pathological conditions, including gram-negative sepsis, atherosclerosis, and cancer, is associated with life-threatening thrombosis (14-16). In sepsis, TF expression within the vasculature leads to disseminated intravascular coagulation (17). TF is expressed by circulating monocytes and also by splenic microvascular endothelial cells in septic baboons $(17,18)$. Inhibition of TF activity in animal models of sepsis prevents endotoxin-induced coagulation and lethality $(19,20)$. In atherosclerosis, plaque rupture and exposure of blood to TF expressed by macrophage-derived foam cells may be responsible for arterial thrombosis $(21,22)$. In addition, patients with unstable angina exhibit elevated levels of monocyte TF expression, which may contribute to a hypercoagulable state (16). Vascular smooth muscle cells also inducibly express TF after angioplasty and may initiate intravascular thrombosis (23). Furthermore, induction of TF activity during postischemic reperfusion is associated with decreased coronary flow (24). Indeed, inhibition of TF activity has been shown to reduce the frequency of occlusion in rabbit models of arterial thrombosis $(25,26)$.

Regulation of the human TF (hTF) gene has been characterized extensively in vitro (for a recent review see reference 27). LPS and cytokine induction in both monocytic cells and endothelial cells is mediated by a distal enhancer ( -227 to -172 , relative to the start site of transcription) containing two AP-1 sites and a $\kappa \mathrm{B}$ binding site (28-32). The $\kappa \mathrm{B}$ site in the TF promoter selectively binds c-Rel-p65 heterodimers (29). The human, murine, rat, and porcine TF promoters are highly conserved (32-35), suggesting that the same or similar regulatory DNA elements control expression of the TF gene in the different mammalian species. However, to date no studies have examined the regulatory regions within these promoters that confer cell type-specific and inducible TF expression in vivo. Studies on the regulation of TF gene expression in vivo may lead to the development of drugs that inhibit TF expression in diseases associated with thrombosis.

In this study, we characterized the in vivo expression of a human TF minigene, which contained the human TF promoter and cDNA. Our results indicated that regulatory elements in the minigene directed both tissue-specific and inducible expression. Moreover, the human TF minigene rescued the embryonic lethality of murine TF null embryos. Adult rescued mice expressed low levels of human TF, suggesting that low TF 


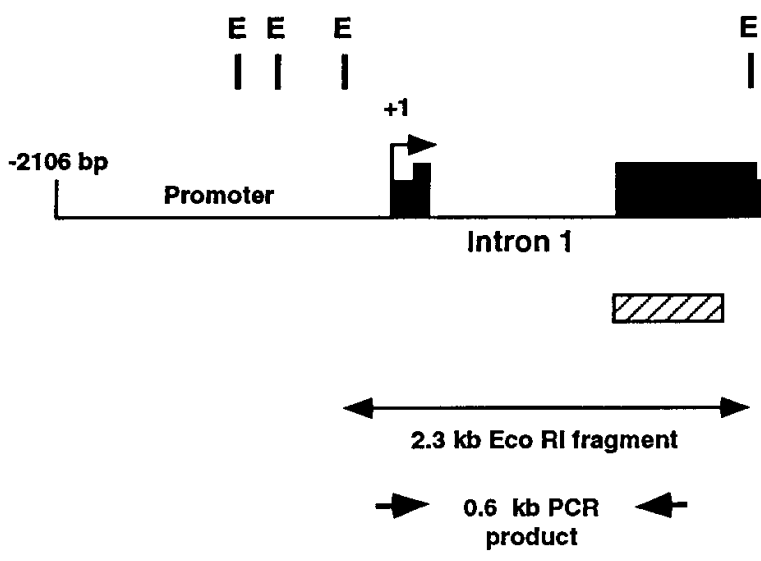

levels can maintain hemostasis compatible with normal survival.

\section{Methods}

Generation of transgenic and rescued mice. The human TF minigene was constructed in pBluescript (Stratagene Cloning Systems, La Jolla, CA) from DNA fragments spanning the human TF gene (34). All intermediates in the cloning were sequenced. The human TF minigene was excised on a 6.1-kbp KpnI-BstXI DNA fragment. The purified DNA was injected into the pronucleus of fertilized mouse embryos (strain CB6[C57BL/6 $\times$ BALB/c]) by the Scripps Transgenic Core facility. Transgenic animals were identified by hybridizing Southern blots of EcoRI-digested tail DNA with a 641-bp human TF cDNA probe (36). Heterozygous $F_{1}$ and $F_{2}$ transgenic progeny were obtained by mating the founder animals with $\mathrm{C} 57 \mathrm{BL} / 6 \mathrm{~J}$ mice. To generate rescued mice, we made a transgenic mouse homozygous for the hTF minigene (\#47/47-5) $\left(\mathrm{mTF}^{+/+}, \mathrm{hTF}^{+/+}\right)(\mathrm{C} 57 \mathrm{BL} / 6[75 \%] \times$ $\mathrm{BALB} / \mathrm{c}[25 \%])$ and crossed this mouse with a mouse heterozygous for the murine TF gene $\left(\mathrm{mTF}^{+/-}, \mathrm{hTF}^{-/-}\right)(129 / \mathrm{Sv}[50 \%] \times \mathrm{C} 57 \mathrm{BL} /$ $6[50 \%])(11)$ to create offspring heterozygous for both murine TF and the hTF minigene $\left(\mathrm{mTF}^{+/-}, \mathrm{hTF}^{+/-}\right)$. Animals were studied between 6 and $12 \mathrm{wk}$ of age.

Isolation and culture of peritoneal exudate cells (PECs). Thioglycollate-elicited PECs were harvested from litter-matched transgenic and nontransgenic mice. PECs were obtained by flushing the peritoneal cavity $3 \mathrm{~d}$ after intraperitoneal injection with $3 \mathrm{ml}$ of a $3 \%$ thioglycollate solution (Difco Laboratories Inc., Detroit, MI). After washing with PBS, PECs were resuspended to a final cell density of $10^{6} / \mathrm{ml}$ in RPMI supplemented with 7\% FBS (Gemini Bioproducts Inc., Calabasas, CA), $2 \mathrm{mM}$ L-glutamine, $50 \mu \mathrm{M}$ 2-mercaptoethanol,

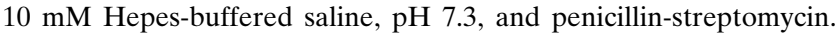
PECs were cultured for 2 or $5 \mathrm{~h}$ at $37^{\circ} \mathrm{C}$ in the presence or absence of LPS $(1 \mu \mathrm{g} / \mathrm{ml}$; Escherichia coli serotype O111:B4; Calbiochem, La Jolla, CA). The protease inhibitor $N^{\alpha}$-tosylphenylalanyl chloromethyl ketone (TPCK) (Calbiochem) was used to inhibit the activation of $\mathrm{NF}-\kappa \mathrm{B} /$ Rel proteins.

Northern blotting and semiquantitative RT-PCR. RNA was isolated from mouse tissue or PECs using Trizol reagent (Life Technologies Inc., Gaithersburg, MD) and quantitated by measuring absorption at $260 \mathrm{~nm}$. For analysis of mRNA expression in whole blood, $250 \mu \mathrm{l}$ of whole blood was mixed with $12.5 \mathrm{ml}$ of a lysis buffer $(0.14 \mathrm{M}$ $\mathrm{NH}_{4} \mathrm{Cl}, 0.017 \mathrm{M}$ Tris, $\mathrm{pH}$ 7.2) to lyse the red blood cells. Next, cells were washed with PBS and RNA isolated using Trizol reagent. The level of various mRNAs was determined by either Northern blotting or semiquantitative RT-PCR using primers specific for human TF (hTF), murine TF (mTF), TNF- $\alpha$ (Clontech), and glyceraldehyde
Figure 1. Schematic representation of the hTF minigene. Filled boxes indicate hTF cDNA sequences (the taller region represents the coding region and the shorter region represents the $5^{\prime}$ and $3^{\prime}$ noncoding regions). Genomic sequences are indicated by a single line and include intron 1 . The bent arrow indicates the start site of transcription at +1 . EcoRI sites in the minigene are indicated $(E)$. The 641-bp human TF cDNA fragment (striped box) hybridizes with a 2.3-kbp EcoRI DNA fragment of the minigene. PCR primers (arrows) spanning intron 1 amplify a 628-bp DNA fragment derived from hTF mRNA. 3-phosphate dehydrogenase (G3PDH) (Clontech). For hTF, two pairs of primers spanning intron 1 that yielded either a 628 -bp product (5' primer $182-207 \mathrm{bp}, 3^{\prime}$ primer $781-810 \mathrm{bp}$ ) or a 363 -bp product (5' primer $182-207 \mathrm{bp}, 3^{\prime}$ primer $524-545 \mathrm{bp}$ ) (numbering from reference 37) were used. For mTF, we used a pair of primers that yielded a 242-bp product ( $5^{\prime}$ primer $448-466 \mathrm{bp}, 3^{\prime}$ primer $671-690 \mathrm{bp}$ ) (numbering from reference 38 ). Reverse transcription was performed using a Superscript preamplification system (Life Technologies Inc.) with $2 \mu \mathrm{g}$ of total RNA per cDNA synthesis reaction. The PCR amplification reaction contained $10 \mathrm{mM}$ Tris- $\mathrm{HCl}, \mathrm{pH} 8.3,1.5 \mathrm{mM} \mathrm{MgCl}_{2}$, $50 \mathrm{mM} \mathrm{KCl}, 0.4 \mu \mathrm{M}$ of each primer, $0.2 \mathrm{mM}$ of each dNTP, $2 \mu \mathrm{lDNA}$ template, and $2.5 \mathrm{U}$ of $\mathrm{Taq}$ polymerase (Boehringer Mannheim Biochemicals, Indianapolis, IN). $2 \mu \mathrm{l}$ of cDNA product was subjected to increasing cycles of PCR to determine the linear range of the PCR reaction (not shown).

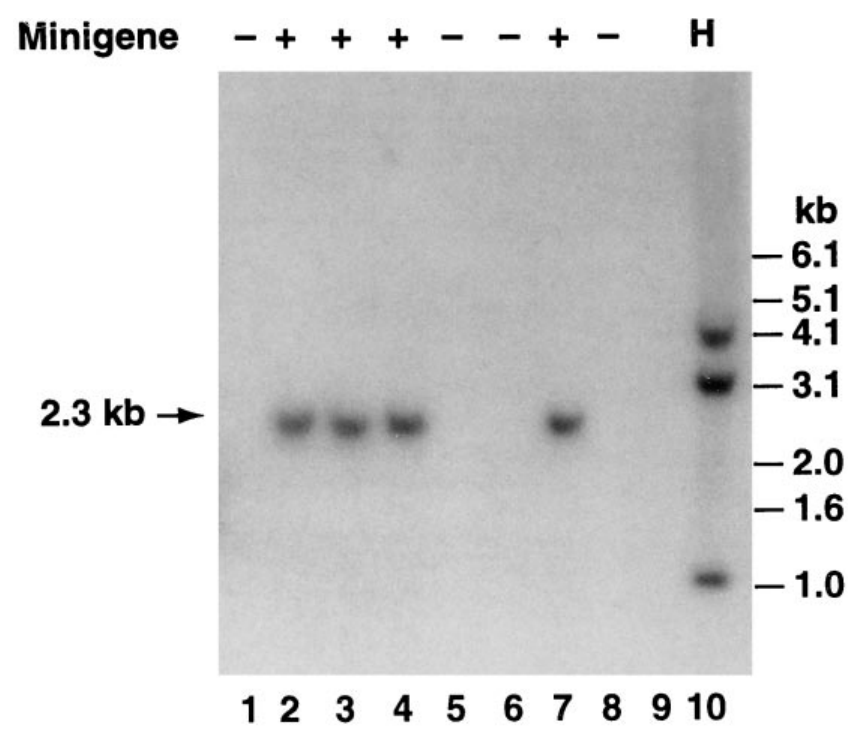

Figure 2. Southern blot analysis of DNA from the offspring of founder \#63. DNA $(10 \mu \mathrm{g})$ was digested with EcoRI and hybridized with a ${ }^{32} \mathrm{P}$-labeled hTF cDNA probe under conditions of high stringency. Lanes 1-8 contain digested mouse tail genomic DNA. Lane 9 is blank. Lane 10 contains $10 \mu \mathrm{g}$ of human $(H)$ DNA digested with EcoRI. The presence $(+)$ or absence $(-)$ of the hTF minigene is indicated above each lane. Molecular weight markers are shown on the right. 
A

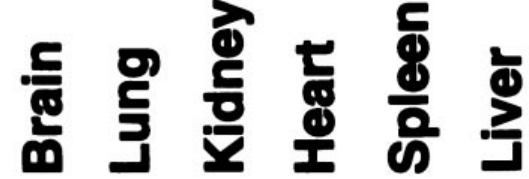

G3PDH

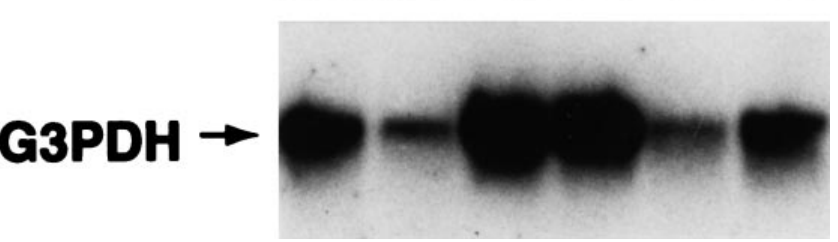

Figure 3. Tissue-specific expression of the hTF mRNA. (A) Total RNA was extracted from brain, lung, kidney, heart, spleen, and liver of a nontransgenic mouse. The tissue distribution of mTF mRNA was determined by Northern blot analysis using an 818-bp mTF cDNA probe (35). The Northern blot was rehybridized with the housekeeping gene G3PDH. (B) Total RNA was extracted from tissues of a transgenic mouse (\#47-37) and mRNA levels were determined by semiquantitative RT-PCR using mTF-specific primers ( 20 cycles), hTF-specific primers (30 cycles), or G3PDH-specific primers (16 cycles). Three independent PCR reactions were performed using different cDNA reactions. PCR products were hybridized with $\mathrm{hTF}, \mathrm{mTF}$, and G3PDH cDNA probes and band intensities were quantitated using NIH Image. Data are shown as the mean of the three PCR reactions \pm standard error. Similar patterns of expression in these six tissues were observed in offspring from an independent founder line (\#63-1). (C) Levels of mTF and hTF mRNAs in the kidney of a transgenic mouse (\#47-37) were determined by quantitative RT-PCR. Determination of the levels of mTF mRNA (242 bp) used $10^{-10}$ to $10^{-16}$ $\mathrm{mol}$ of the competitor plasmid (370 bp) (lanes 2-8). Determination of the levels of hTF mRNA (363 bp) used $10^{-13}$ to $10^{-19}$ mol of the competitor plasmid (330 bp) (lanes 2-8). Lane 1 contains molecular weight markers $(M)$. Controls are mRNA alone (lane 9), competitor plasmid alone (lane 10), and buffer (lane 11).

Quantitative PCR. A synthetic DNA competitor template containing oligomers specific for $\mathrm{mTF}$ and hTF was constructed by PCR amplification of the plasmid pCCF, which contains a 282-bp intervening sequence (22). The PCR product was cloned into pBluescript (Stratagene) and was used as a DNA competitor to quantify cDNA expression. For hTF, the mRNA and competitor products were 363 and $330 \mathrm{bp}$, respectively. For mTF, the mRNA and competitor products were 242 and $370 \mathrm{bp}$, respectively. PCR products were quantified by competitive PCR essentially as described (39). PCR products were separated on 2 or $2.5 \%$ agarose gels and visualized by ethidium bromide staining. Images were captured using an Eagle-Eye II still video system (Stratagene) and band intensities were measured using NIH Image software. $\log _{10}$ (absorbance control/absorbance mRNA) $(y$ axis) was plotted against $\log _{10}$ (number of control molecules) ( $x$ axis). When the competitor and mRNA were present at equal amounts, the $\log _{10}$ (control/mRNA) equaled zero. Quantitative PCR results were expressed as the number of cDNA molecules per nanogram of RNA.

Determination of human TF antigen and functional activity. TF functional activity was determined from brain extracts or PECs in a one-stage clotting assay using either mouse (Sigma Chemical Co., St. Louis, MO) or human plasma as described (40). Brain extracts were prepared by homogenizing brain tissue in $15 \mathrm{mM}$ octyl- $\beta$-D-glucopy-
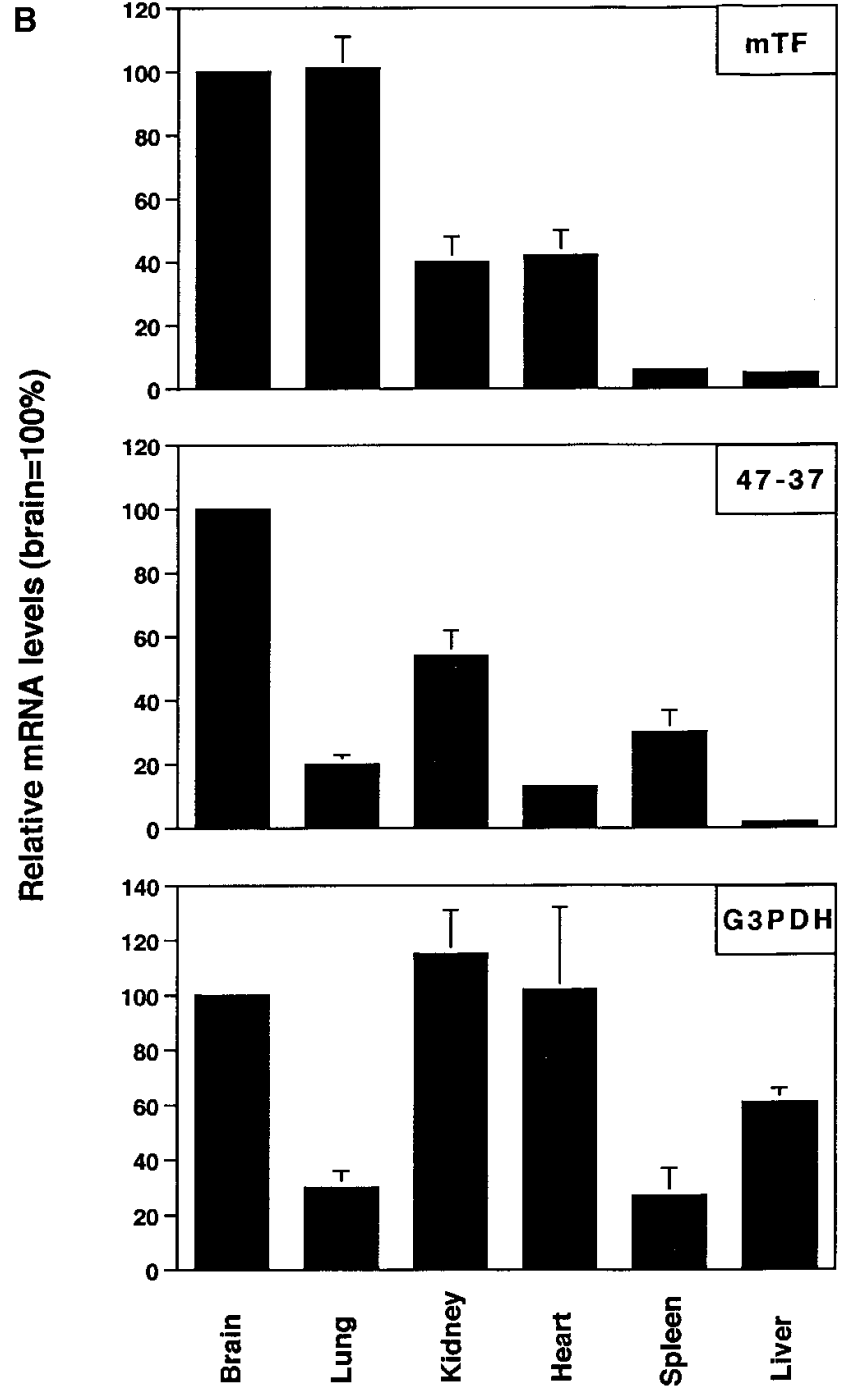

ranoside, centrifuging at $12,000 \mathrm{~g}$ for $1 \mathrm{~min}$, and incubating the supernatants at $37^{\circ} \mathrm{C}$ for $15 \mathrm{~min}$. PECs were solubilized with $15 \mathrm{mM}$ octyl$\beta$-D-glucopyranoside at $37^{\circ} \mathrm{C}$ for $15 \mathrm{~min}$. TF functional activity was calculated in arbitrary units by reference to a standard curve. Human TF clots both human and mouse plasma, whereas mouse TF clots only mouse plasma (41). hTF activity was inhibited with anti-human TF monoclonal antibodies (TF8-5G9, TF8-6B4, and TF9-9C3) (40). hTF antigen was measured using a monoclonal antibody capture system ELISA (IMUBIND tissue factor ELISA kit; American Diagnostica Inc., Greenwich, CT), which does not detect murine TF.

Electrophoretic mobility shift assay (EMSA). Nuclear extracts were prepared from unstimulated and LPS-stimulated $(1 \mu \mathrm{g} / \mathrm{ml}$ for $2 \mathrm{~h}$ ) PECs $\left(5 \times 10^{6}\right.$ cells $)$ as described (29). Nuclear extracts were incubated with a radiolabeled TF $\kappa$ B site probe (29) and protein-DNA complexes were separated from free DNA probe by electrophoresis through $6 \%$ nondenaturing, polyacrylamide gels. Antibody supershift experiments were performed using anti-p65, anti-p50, and anti-c-Rel antibodies (Santa Cruz Biotechnology, Santa Cruz, CA) to identify proteins present in the complex (29).

Immunohistochemistry. Human or murine TF antigens in murine tissues were detected by antigen retrieval (8) using a goat anti-human TF polyclonal antibody (American Diagnostica \#4501) $(1: 200,5 \mu \mathrm{g} / \mathrm{ml})$ 

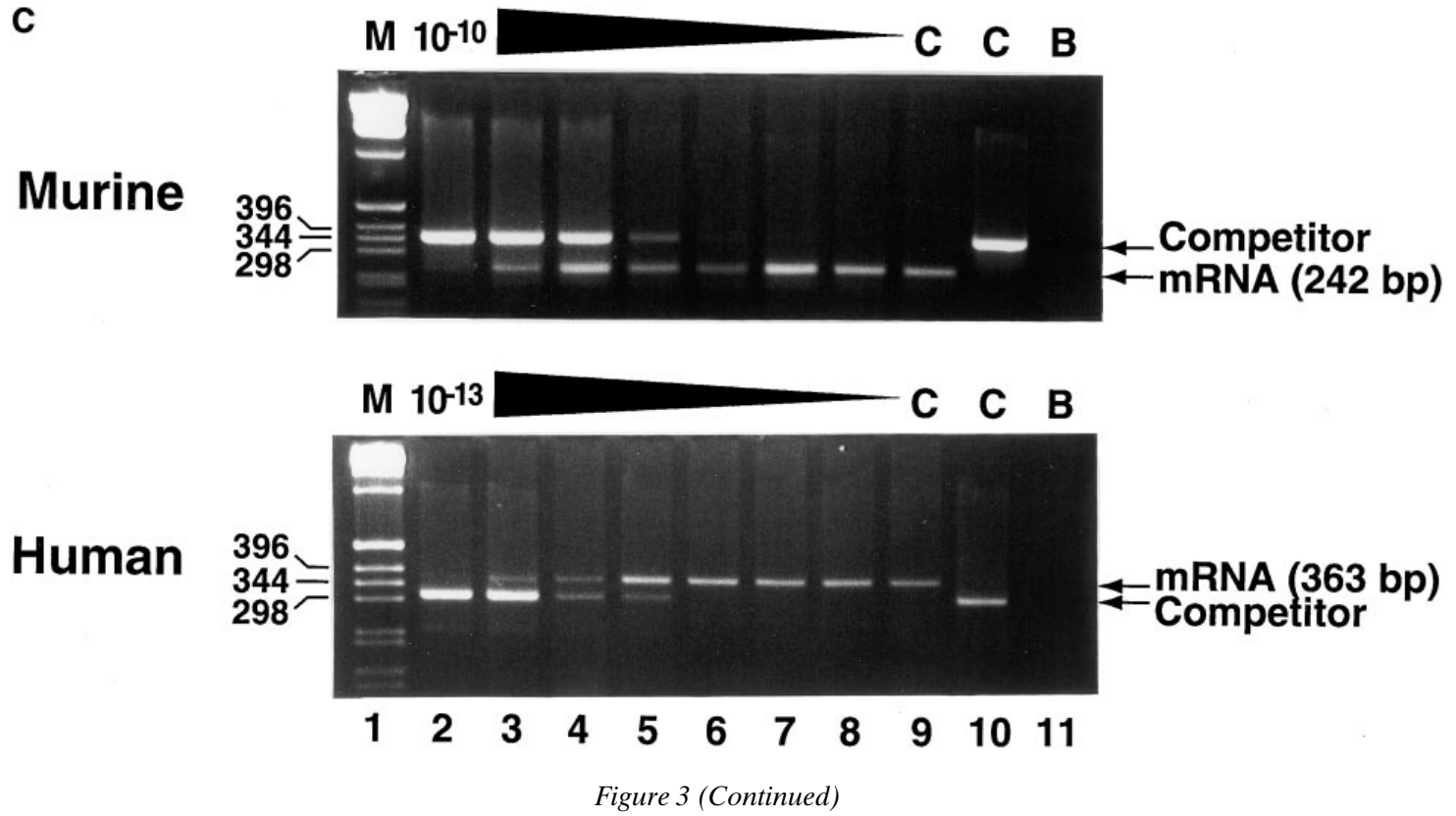

on formalin-fixed, paraffin-embedded, $4-\mu \mathrm{M}$-thick sections. The goat anti-human TF antibody cross-reacts with mouse TF on Western blots (not shown). Control sections were stained with nonimmune goat immunoglobulin. Tissue sections were incubated with the primary antibody overnight at $4^{\circ} \mathrm{C}$. Goat antibody was detected with the Vectastain Elite kit (Vector Laboratories, Burlingame, CA) using a biotinylated anti-goat immunoglobulin and 3,3'-diaminobenzidine, which produced a brown reaction product. Human and murine TF antigens were also localized in murine tissues using an affinity-purified rabbit anti-human TF polyclonal antibody on 6- $\mu \mathrm{M}$ fresh-frozen sections.

\section{Results}

Generation of transgenic mice. Our previous studies indicated that a transgene containing $1.0 \mathrm{kbp}$ of the mTF promoter cloned upstream of the lac $\mathrm{Z}$ reporter gene was not expressed in transgenic mice (Drake, T.A., G.C.N. Parry, and N. Mackman, unpublished data). This experience led us to include intron 1 in a hTF minigene (Fig. 1), which we believed would facilitate efficient expression by promoting RNA splicing and may include regulatory elements that would contribute to TF expression in vivo. Screening of 93 offspring from the injection of the hTF minigene into fertilized mouse embryos identified 12 founder mice. Analysis of the offspring from crosses between founder mice and wild-type C57BL/6 mice revealed germline transmission of the hTF minigene (Fig. 2) in 11 out of the 12 founders. The radiolabeled hTF cDNA did not hybridize with the mTF gene under the high stringency conditions used in the Southern blots. Comparison of the band intensities of the hTF minigene with that of human genomic DNA indicated

\section{A. ELISA}

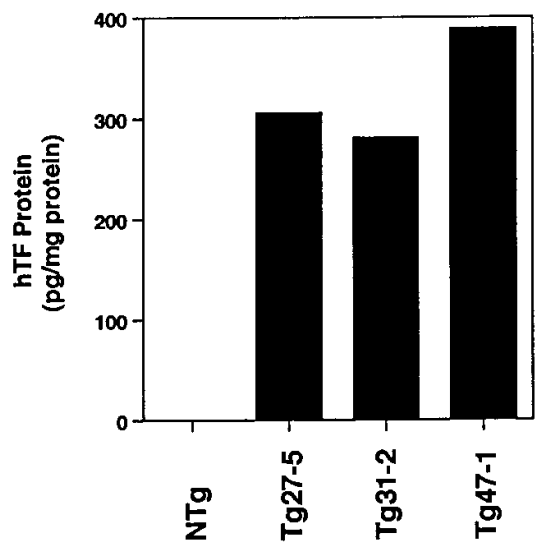

B. Clotting

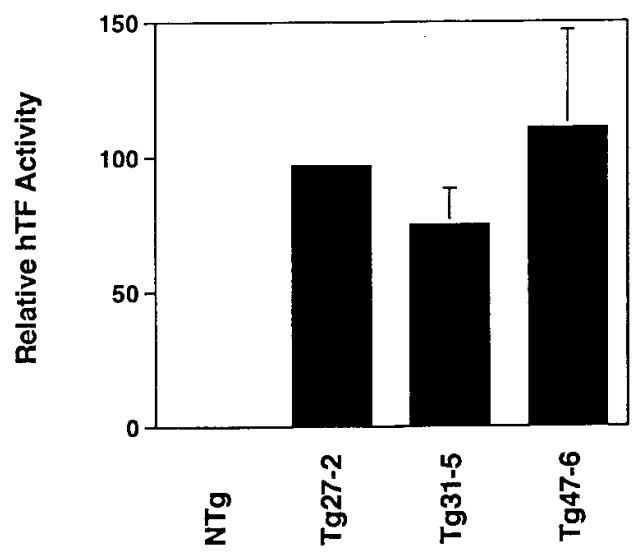

Figure 4. Detection of hTF expression in the brain of transgenic mice. $(A)$ hTF antigen in brain extracts from three transgenic mice $(T g)$ and a nontransgenic $(N T g)$ mouse was analyzed by ELISA. (B) hTF activity was measured using a single-step clotting assay with human plasma. Clotting times of detergent extracts of brain tissue from three transgenic mice and a nontransgenic mouse were determined from a standard curve $(\mathrm{mU} / \mathrm{ml})$ for purified human TF. Results of triplicate determinations are shown (mean $\pm \mathrm{SD})$. The procoagulant activity of the brain extract from the nontransgenic mouse $(25 \mathrm{mU} / \mathrm{ml})$ was subtracted from the total procoagulant activity of brain extracts from transgenic mice. 

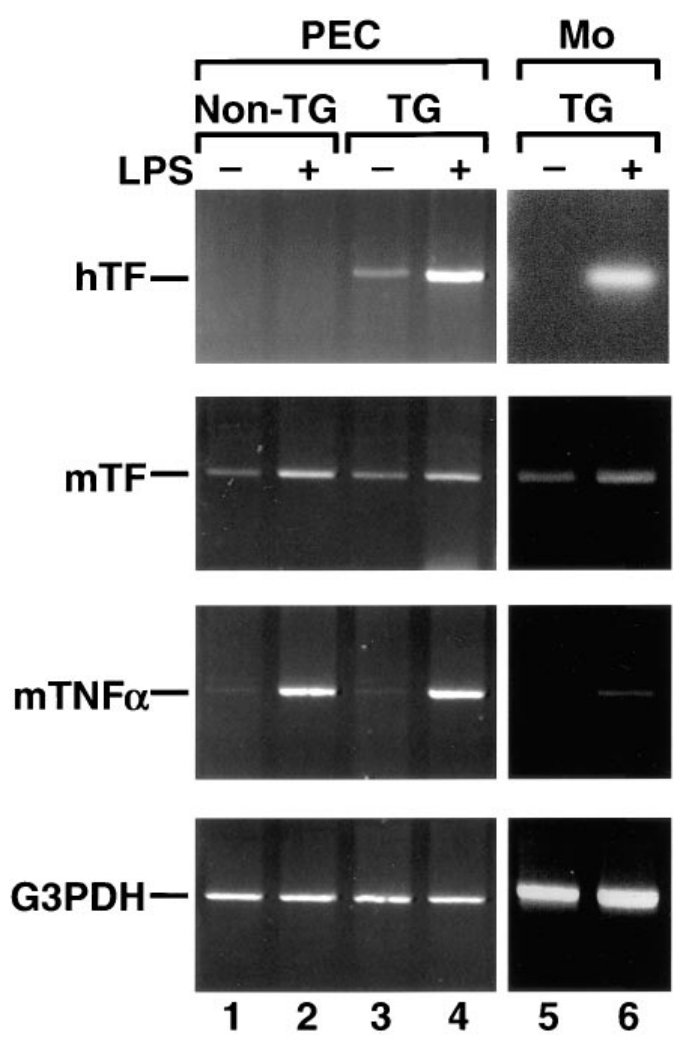

Figure 5. LPS induction of the hTF mRNA expression. Thioglycollate-elicited PECs from nontransgenic (Non-TG) mice or transgenic (TG) mice (pooled from \#63-7 and \#63-21) were incubated in the presence $(+)$ or absence $(-)$ of LPS $(1 \mu \mathrm{g} / \mathrm{ml})$ for $2 \mathrm{~h}$. Total RNA was extracted and the expression of hTF ( 30 cycles), mTF ( 20 cycles), mTNF- $\alpha$ ( 16 cycles), and G3PDH (16 cycles) mRNAs was determined by semiquantitative RT-PCR. Similar results were observed using PECs from transgenic mouse \#47-8 (not shown). Whole blood from transgenic mice (pooled from \#4747-16, \#4747-18, and \#4747-19) was stimulated with LPS $(1 \mu \mathrm{g} / \mathrm{ml})$ for $2 \mathrm{~h}$. For whole blood, expression of the various mRNAs was determined as follows: hTF ( 35 cycles), mTF ( 30 cycles), TNF- $\alpha$ ( 25 cycles), and G3PDH ( 25 cycles). PCR products were separated on $2 \%$ agarose gels and visualized by staining with ethidium bromide. The hTF product from whole blood was Southern blotted and hybridized with a 641-bp human TF cDNA probe.

that 9 of the 11 founders contained a single copy of the minigene. No phenotypic abnormalities were associated with the presence of the hTF minigene.

Tissue-specific expression of the hTF minigene. Expression of the human TF minigene was analyzed primarily in two founder lines (\#47 and \#63), although similar expression patterns were observed in five additional founder lines (\#23, \#27, $\# 31$, \#45, and \#76). Initial studies analyzed expression of hTF mRNA in the brain of transgenic mice. RT-PCR was used because no signal was detected by Northern blotting. A 628-bp PCR product was observed with hTF-specific primers using total RNA from a transgenic mouse but not from a nontransgenic littermate (not shown). This PCR product was dependent on reverse transcriptase and hybridized with a radiolabeled hTF cDNA, indicating that hTF mRNA was expressed in vivo.

Tissue-specific expression of hTF mRNA was examined in transgenic mice. For comparison, mTF mRNA expression was measured by both Northern blotting and semiquantitative RTPCR, which revealed highest levels in the brain and lung, intermediate levels in the kidney and heart, and low levels in the spleen and liver (Fig. 3, $A$ and $B$ ). The housekeeping gene G3PDH is expressed at different levels in these six tissues. Various levels of hTF mRNA were observed by semiquantitative RT-PCR in tissues from transgenic mouse \#47-37 (brain $>$ kidney $>$ spleen $>$ lung $>$ heart $>$ liver) (Fig. 3 B). Similar patterns of hTF mRNA expression were observed in another founder line 63 (not shown), suggesting that the expression pattern of the hTF minigene was not affected by the site of integration. To more accurately quantitate the expression level of the hTF minigene, hTF mRNA in transgenic mice was measured by quantitative RT-PCR (Fig. $3 C$ ). The brain and the kidney were chosen because they contained relatively high levels of hTF mRNA compared with the other tissues. The level of hTF mRNA $\left(2.5 \times 10^{6}\right.$ molecules/ng RNA $)$ in the brain of line \#47-37 was $1.0 \%$ of the level of mTF mRNA $\left(2.4 \pm 1.0 \times 10^{8}\right.$ molecules/ng RNA). The level of hTF mRNA $\left(1.8 \pm 0.9 \times 10^{6}\right.$ molecules/ng RNA, mean \pm SD) in the kidneys of two transgenic mice (\#47-3 and \#47-37) was $0.8 \%$ of the level of $\mathrm{mTF}$ mRNA $\left(2.3 \pm 1.1 \times 10^{8}\right.$ molecules/ng RNA, mean $\left.\pm \mathrm{SD}, n=5\right)$. Similar low levels of hTF mRNA $\left(1.7 \pm 0.5 \times 10^{6}\right.$ molecules/ng RNA) were observed in the kidneys of two offspring (\#63-1 and \#63-9) from an independent founder. Taken together, these data suggest that the hTF was expressed at low levels in a tissue-specific manner.

Next, we determined the level of hTF antigen and functional activity in brain extracts from transgenic mice using an ELISA and clotting assay, respectively. hTF antigen was detected in brain extracts from transgenic mice but not from a nontransgenic mouse (Fig. $4 A$ ). No statistically significant difference in the procoagulant activity of brain extracts from transgenic and nontransgenic mice was observed using a clotting assay with mouse plasma (see Fig. 10). Therefore, we used a clotting assay with human plasma that detects human TF activity and not mouse TF (41). Brain extracts from transgenic mice contained hTF activity (Fig. $4 \mathrm{~B}$ ), which was abolished by neutralizing anti-human TF monoclonal antibodies (not shown).

LPS induction of the hTF minigene. To examine if expression of the hTF minigene was inducible, we measured hTF mRNA levels by semiquantitative RT-PCR in unstimulated and LPS-stimulated PECs and whole blood from transgenic mice. LPS strongly induced hTF mRNA expression in both PECs and whole blood, presumably due to expression by peritoneal macrophages and peripheral blood monocytes, respectively (Fig. 5). LPS also induced mTF mRNA expression in PECs from both nontransgenic and transgenic littermates and in whole blood from transgenic mice (Fig. 5), although the magnitude of induction of the endogenous mTF gene was significantly less than the induction of the hTF minigene. TNF- $\alpha$ mRNA expression was induced in PECs and whole blood treated with LPS. Expression of hTF antigen in PECs from transgenic mice was induced by LPS (Fig. $6 A$ ). LPS stimulation also induced the expression of hTF activity in PECs from transgenic mice as measured in human plasma, which was abolished by anti-human TF monoclonal antibodies (Fig. 6B).

The role of NF-кB/Rel proteins in the LPS induction of the hTF minigene in PECs was assessed by EMSA and by the use of a specific NF-кB/Rel inhibitor. LPS stimulation of PECs induced the nuclear translocation of $N F-\kappa B / R e l$ proteins that 
A. ELISA

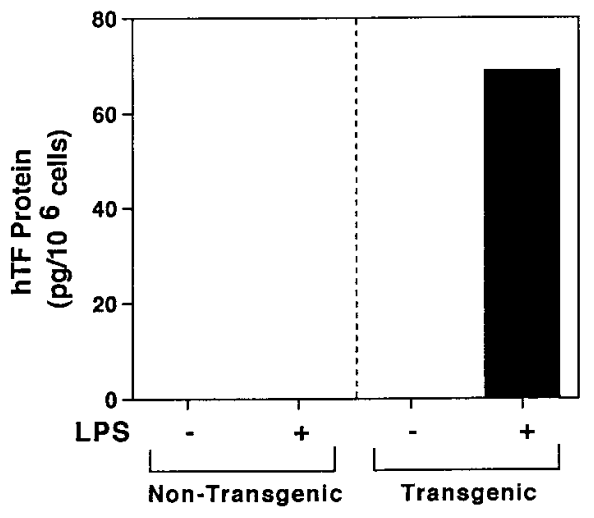

B. Clotting

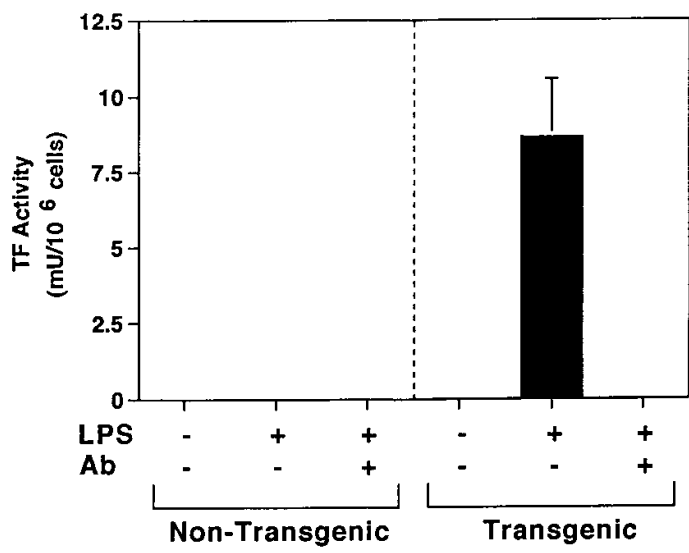

Figure 6. LPS induction of hTF expression in PECs from transgenic mice. $(A)$ hTF antigen in unstimulated and LPS-stimulated PECs from transgenic mice (\#63-7 and \#63-21) or nontransgenic littermates was determined by ELISA. Similar results were obtained with PECs from two independent founder lines (\#27 and \#47). (B) hTF activity with human plasma was determined in unstimulated and LPSstimulated $(1 \mu \mathrm{g} / \mathrm{ml}$ for $5 \mathrm{~h})$ PECs pooled from either transgenic (\#63-7 and \#63-21) or nontransgenic littermates. hTF activity was abolished by incubation with monoclonal an-

tibodies $(A b)(10 \mu \mathrm{g} / \mathrm{ml})$ against human TF. Similar results were observed using transgenic mice \#47-9 (not shown). The procoagulant activity of LPS-stimulated PECs from the nontransgenic mouse $\left(4.3 \mathrm{mU} / 10^{6}\right.$ cells) was subtracted from the total procoagulant activity of unstimulated and LPS-stimulated PECs from transgenic mice.

bound to the TF $\kappa \mathrm{B}$ site (Fig. $7 A$ ). Antibody supershift experiments demonstrated that the TF complex was comprised of c-Rel and p65 (Fig. 7 B). Our previous studies indicated that TPCK, an inhibitor of NF-кB/Rel proteins, blocked LPS induction of TF expression in human monocytes and monocytic cells (42). Similarly, TPCK inhibited LPS induction of hTF antigen expression in PECs (Fig. 7 C). These studies indicate that LPS induces expression of the hTF minigene in murine PECs via an NF-кB/Rel-dependent mechanism.
Rescue of murine TF null embryos with the human TF minigene. Recently, we demonstrated that targeted disruption of the mTF gene results in embryonic lethality between days E9.5 and 10.5 (11). Therefore, we examined if the hTF minigene could rescue the embryonic lethality in murine TF null embryos. Five independent crosses $\left(\mathrm{mTF}^{+/-}, \mathrm{hTF}^{+/-} \times \mathrm{mTF}^{+/-}\right.$, $\mathrm{hTF}^{+/-}$) were set up (Table I). If the hTF minigene rescued the embryonic lethality of mTF null embryos, $20 \%$ of weaned pups ( $3 \mathrm{wk}$ ) would be expected to survive due to the presence
A

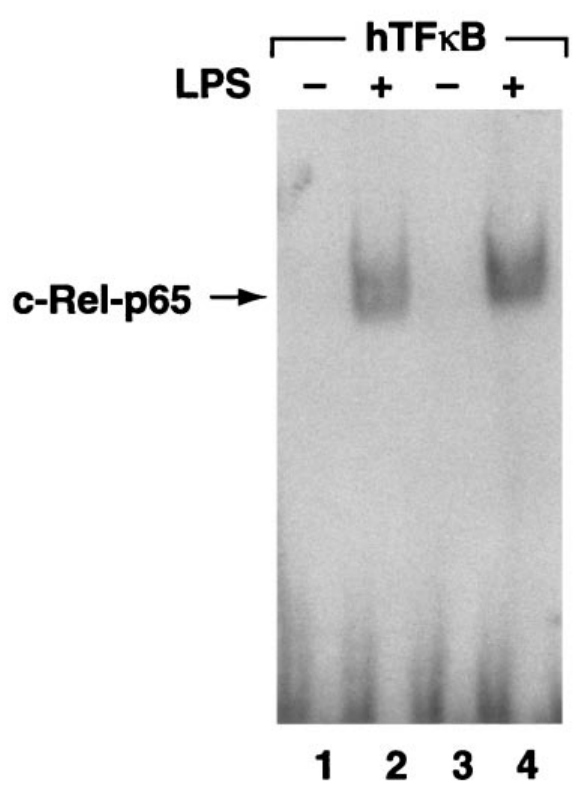

B

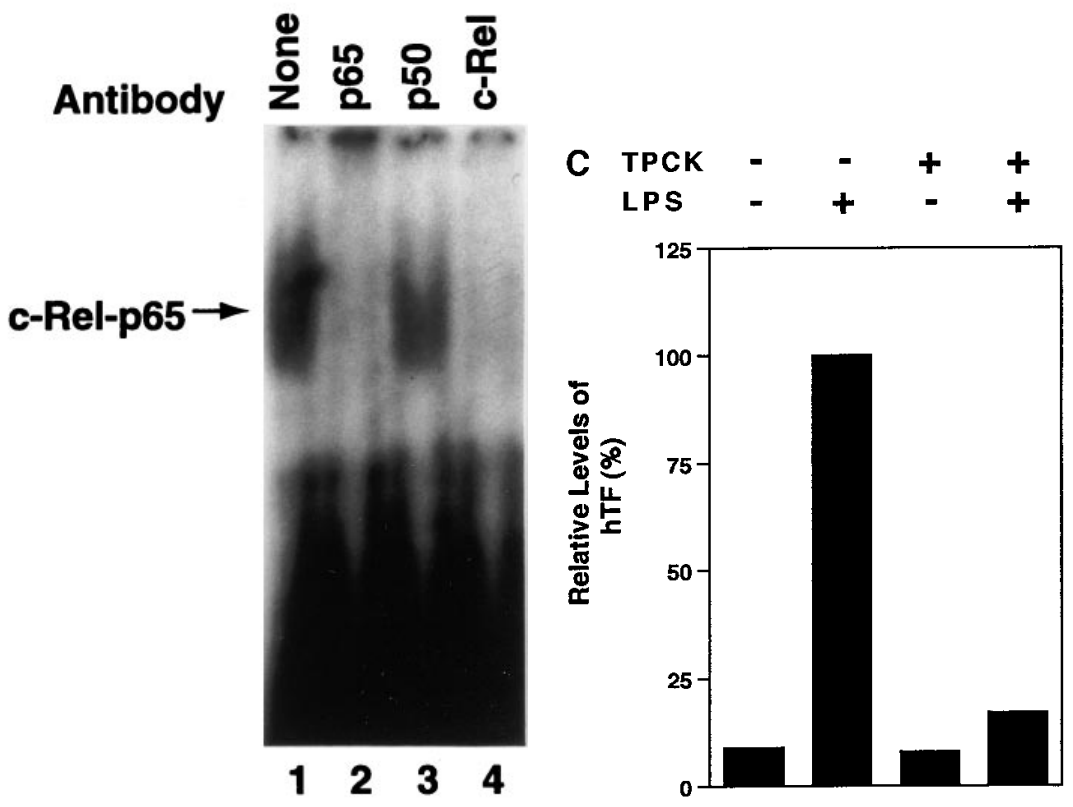

Figure 7. LPS induces expression of hTF in PECs via an NF-кB-dependent mechanism. $(A)$ Nuclear extracts from PECs with or without LPS stimulation $(1 \mu \mathrm{g} / \mathrm{ml}$ for $2 \mathrm{~h})$ were incubated with a radiolabeled TF $\kappa B$ site. Protein-DNA complexes were analyzed by EMSA. Lanes 1 and 2 show PECs from a nontransgenic mouse and lanes 3 and 4 show PECs from a transgenic mouse. $(B)$ Antibody supershift experiments were performed by incubating protein-DNA complexes with anti-p65, anti-p50, and anti-c-Rel antibodies (Santa Cruz Biotechnology). $(C)$ hTF antigen levels were determined in unstimulated and LPS-stimulated PECs from transgenic mice (\#47-7 and \#47-8) in the presence or absence of TPCK (5 $\mu M)$. Similar results were observed using transgenic mice 63-29 and 63-30 (not shown). 
Table I. Offspring from $m \mathrm{mF}^{+/-}, h T F^{+/-} \times m \mathrm{mF}^{+/-}, h \mathrm{TF}^{+/-}$

\begin{tabular}{|c|c|c|c|c|}
\hline Alleles & $\mathrm{mTF}^{+}, \mathrm{hTF}^{+}$ & $\mathrm{mTF}^{+}, \mathrm{hTF}^{-}$ & $\mathrm{mTF}^{-}, \mathrm{hTF}^{+}$ & $\mathrm{mTF}^{-}, \mathrm{hTF}^{-}$ \\
\hline $\mathrm{mTF}^{+}, \mathrm{hTF}^{+}$ & $\mathrm{mTF}^{+/+}, \mathrm{hTF}^{+/+}$ & $\mathrm{mTF}^{+/+}, \mathrm{hTF}^{+/-}$ & $\mathrm{mTF}^{+/-}, \mathrm{hTF}^{+/+}$ & $\mathrm{mTF}^{+/-}, \mathrm{hTF}^{+/-}$ \\
\hline $\mathrm{mTF}^{+}, \mathrm{hTF}^{-}$ & $\mathrm{mTF}^{+/+}, \mathrm{hTF}^{-/+}$ & $\mathrm{mTF}^{+/+}, \mathrm{hTF}^{-/-}$ & $\mathrm{mTF}^{+/-}, \mathrm{hTF}^{+/-}$ & $\mathrm{mTF}^{+/-}, \mathrm{hTF}^{-/-}$ \\
\hline $\mathrm{mTF}^{-}, \mathrm{hTF}^{+}$ & $\mathrm{mTF}^{-/+}, \mathrm{hTF}^{+/+}$ & $\mathrm{mTF}^{-/+}, \mathrm{hTF}^{+/-}$ & $\mathrm{mTF}^{-/-}, \mathrm{hTF}^{+/+}$ & $\mathrm{mTF}^{-1-}, \mathrm{hTF}^{+/-}$ \\
\hline $\mathrm{mTF}^{-}, \mathrm{hTF}^{-}$ & $\mathrm{mTF}^{-/+}, \mathrm{hTF}^{-/+}$ & $\mathrm{mTF}^{-l+}, \mathrm{hTF}^{-/-}$ & $\mathrm{mTF}^{-1-}, \mathrm{hTF}^{-1+}$ & $\mathrm{mTF}^{-1-}, \mathrm{hTF}^{-1-}$ \\
\hline
\end{tabular}

Shaded boxes represent rescued $\mathrm{mTF}^{-/-}$mice.

of the human TF minigene. Screening of tail DNA from 117 weaned offspring identified 17 pups (14\%) homozygous for the targeted mTF gene and containing the hTF minigene. A representative Southern blot is shown in Fig. 8. No $\mathrm{mTF}^{-1-}$, $\mathrm{hTF}^{-l-}$ mice have been observed at $3 \mathrm{wk}$. In a second breeding strategy, a rescued male heterozygous for the minigene $\left(\mathrm{mTF}^{-/-}, \mathrm{hTF}^{+/-}\right)$was crossed with a female heterozygous for murine $\mathrm{TF}$ and homozygous for the hTF minigene $\left(\mathrm{mTF}^{+/-}\right.$, $\mathrm{hTF}^{+/+}$) (Table II). In this breeding, we expected $50 \%$ of the offspring to be rescued mice. So far, three litters have yielded $55 \%$ rescued offspring (12 of 22). These results demonstrate that the hTF minigene rescues murine TF null embryos, suggesting that human TF is expressed during embryonic development.

Analysis of hTF expression in rescued mice. The tissue-specific expression of hTF in a rescued mouse (R47-23) was consistent with the pattern observed in transgenic mice (not

\section{Offspring: $1 \begin{array}{llllllll}1 & 2 & 3 & 4 & 5 & 6 & 7 & 8\end{array}$

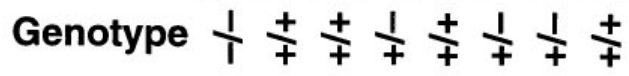

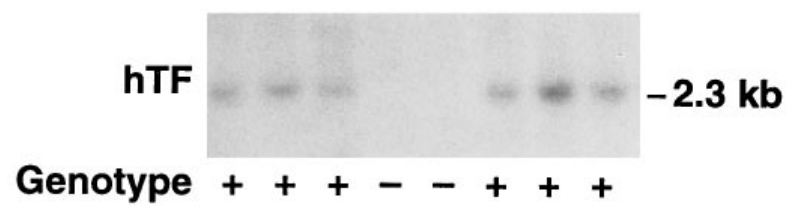

Figure 8. Rescue of the embryonic lethality of mTF null embryos with the hTF minigene. A StuI/EcoRV digest (top) of tail DNA from 4-wk-old offspring (1-8) from a cross shown in Table I was hybridized with a genomic DNA probe (2.4-kbp SacI-HindIII, -6.0 to -3.6 ), which recognizes either a 10.0-kbp DNA fragment from the wild-type allele or an 8.0-kbp DNA fragment from the disrupted allele (11). The genotype of each offspring is shown below. Offspring 1 (highlighted) contains two mutant alleles. An EcoRI digest of tail DNA from the same offspring was probed with a 641-bp hTF cDNA fragment to detect the hTF minigene. The presence $(+)$ or absence $(-)$ of the minigene is shown below. shown). Cell type-specific expression of the hTF minigene in rescued mice (R47-14 and R47-23) was analyzed by immunohistochemistry. One of the most striking species-specific differences in the pattern of TF expression between the human and the mouse occurs in the kidney where hTF is expressed in the glomeruli, whereas mTF is expressed in the tubules (8). In a rescued mouse (R47-14), the hTF minigene exhibited a mouse pattern of expression with hTF protein being strongly expressed by tubular epithelial cells with little or no staining in glomerular cells (Fig. 9, $A$ and $B$ ). A low level of nonspecific staining of renal tubules was observed with nonimmune goat immunoglobulin (Fig. 9, $D$ and $E$ ). hTF protein was also expressed in the epidermis of the tongue, adventitial cells surrounding blood vessels, bronchial epithelium, cardiac myocytes, and brain astrocytes in both formalin-fixed and frozen sections (data not shown) in a pattern similar to that of mTF and hTF protein $(8,43)$.

Transgenic mice containing the hTF minigene expressed low levels of hTF mRNA $(\sim 1 \%)$ relative to mTF mRNA. This low level expression of hTF may be due to some form of repression by the mTF gene. Therefore, the level of human TF expression was measured in a rescued mouse that did not contain a functional mTF gene. Brain extracts from a rescued mouse contained a low level of hTF antigen (263 pg/mg protein), which is similar to the levels of hTF antigen in brain extracts from transgenic mice. The total procoagulant activity of brain extracts from a rescued mouse (R47-23) was very low $(\sim 0.7 \%)$ compared with a wild-type mouse in a clotting assay with mouse plasma (Fig. 10), indicating a low functional TF activity in rescued mice. The procoagulant activity of brain extracts from transgenic and nontransgenic mice was not statistically different using mouse plasma. These results indicate that transgenic and rescued mice express a similar low level of hTF mRNA and protein. Rescued mice developed normally, exhibited no excessive hemorrhage from tail transection for genotyping or spontaneous hemorrhages, and were fertile. Rescued

Table II. Offspring from $m \mathrm{TF}^{-/-}, h T F^{+/-} \times m T F^{+/-}, h T F^{+/+}$

\begin{tabular}{lll}
\hline $\begin{array}{c}\text { Alleles } \\
\text { Alleles }\end{array}$ & & \\
\hline $\mathrm{mTF}^{+}, \mathrm{hTF}^{+}$ & $\mathrm{mTF}^{-}, \mathrm{hTF}^{+}$ & $\mathrm{mTF}^{-}, \mathrm{hTF}^{-}$ \\
$\mathrm{mTF}^{-}, \mathrm{hTF}^{+}$ & $\mathrm{mTF}^{+/-}, \mathrm{hTF}^{+/+}$ & $\mathrm{mTF}^{+/-}, \mathrm{hTF}^{+/-}$ \\
$\mathrm{mTF}^{-/-}, \mathrm{hTF}^{+/+}$ & $\mathrm{mTF}^{-/-}, \mathrm{hTF}^{+/-}$ \\
\hline
\end{tabular}

Shaded boxes represent rescued $\mathrm{mTF}^{-/-}$mice. 

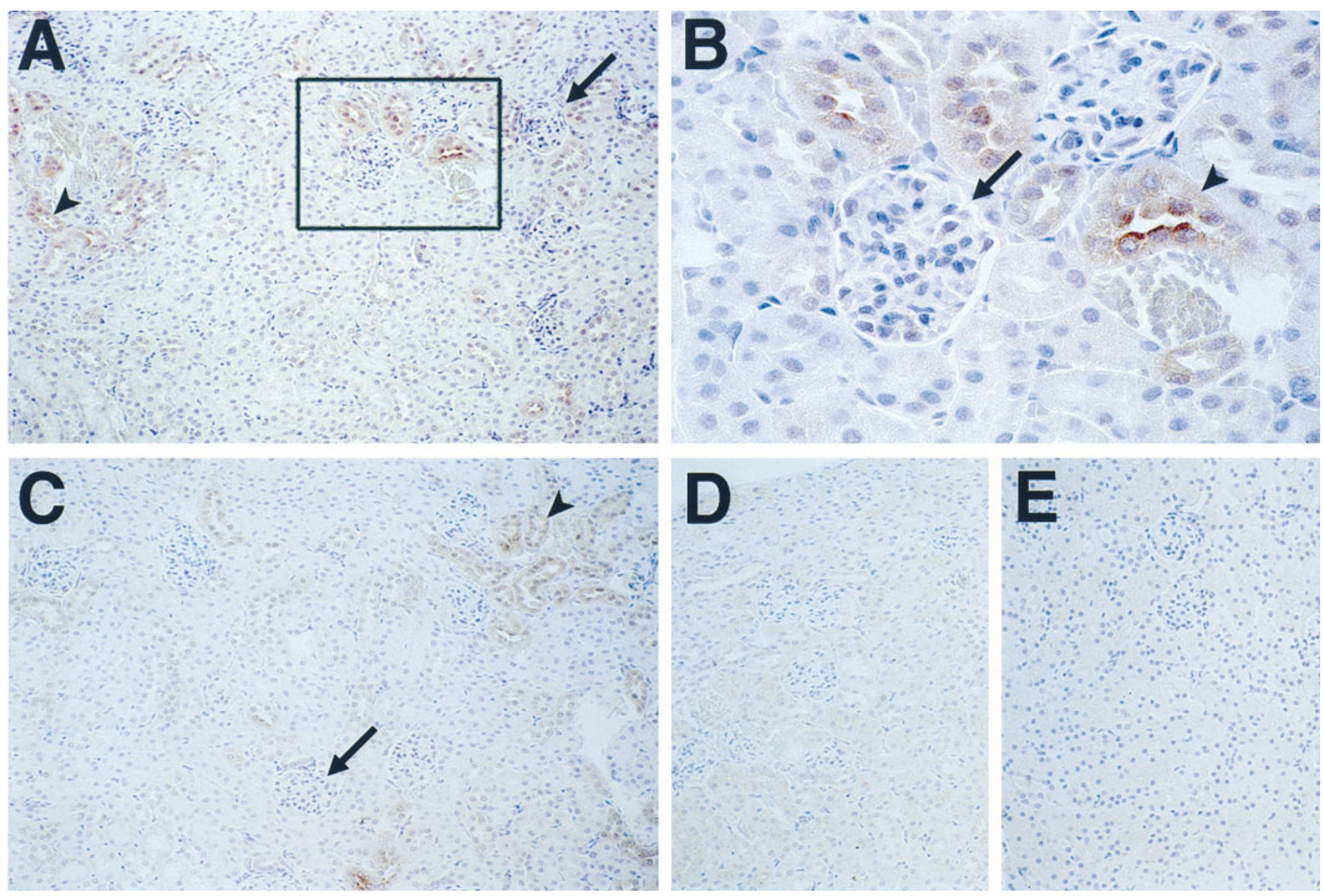

Figure 9. Expression of hTF protein in the kidney of a rescued mouse. Photomicrographs of renal cortical tissue demonstrating the distribution of hTF and mTF antigen by immunoperoxidase staining using a polyclonal goat anti-human TF antibody (American Diagnostica) and 3, 3'diaminobenzidine as reaction product (brown). (A) Localization of hTF antigen in renal tubules of the kidney of a rescued mouse (R47-14) $(\times 50)$. (B) Higher magnification $(\times 250)$ of the area outlined in $A$ demonstrating tubular staining. $(C)$ Localization of murine TF antigen in renal tubules of the kidney of a wild-type mouse $(\times 50)$. Staining with nonimmune goat immunoglobulin as the primary antibody on kidney sections from a wild-type and a rescued mouse is shown in $D$ and $E$, respectively. Arrows indicate the position of glomeruli, and arrowheads indicate the position of tubules. Similar results were observed with a second rescued mouse (R47-23) (not shown).

mice exhibit no reduction in viability up to 7 mo of age. These data suggest that low levels of TF can maintain hemostasis that is compatible with normal survival.

\section{Discussion}

Our previous study failed to detect expression of $\beta$-galactosidase mRNA or protein from a transgene containing $1.0 \mathrm{kbp}$ of the mTF promoter cloned upstream of the lac Z reporter (Drake, T.A., G.C.N. Parry, and N. Mackman, unpublished data). These results contrast with the expression of the hTF minigene shown here, indicating that additional DNA sequences in the hTF promoter, intron 1, or the $3^{\prime}$ flanking region are required for TF gene expression in vivo. Many of the cis-acting regulatory elements that control TF gene expression in vitro are located in the proximal promoter region $(-266$ to +14) (27) and are highly conserved between the human and murine TF promoters (35), suggesting that the successful in vivo expression of the hTF minigene may be due to DNA elements present in intron 1 . Indeed, DNA elements that regulate cell type-specific expression in vivo have been reported in intronic sequences of genes such as PDGF-A and Tie $2(44,45)$.
Future studies will elucidate the relative contributions of the distal promoter region $(-2.1$ to $-1.0 \mathrm{kbp})$, intron 1 , and the $3^{\prime}$ flanking region to the regulation of TF expression in vivo.

The tissue-specific pattern of the hTF minigene was distinct from that of the endogenous mTF gene. Differences in the expression patterns of hTF mRNA and mTF mRNA may be due, in part, to species-specific differences in TF expression and/or an absence of both positive and negative regulatory elements in the minigene. Quantitation of the expression levels of the hTF minigene in two founder lines indicated that hTF mRNA in the kidney and brain of transgenic mice was $\leq 1.0 \%$ of the level of mTF mRNA. Similarly, low levels of hTF antigen were detected in brain extracts of mice from three founder lines. This low level of expression of the hTF minigene in transgenic mice suggests that the minigene may lack a positively acting enhancer or that the murine transcription factors inefficiently recognize regulatory elements in the human TF gene.

Despite the low levels of hTF expression in transgenic mice, the hTF minigene directed cell type-specific expression of hTF protein that closely resembled expression of human and murine TF $(12,13,46,47)$. Human TF was expressed in 


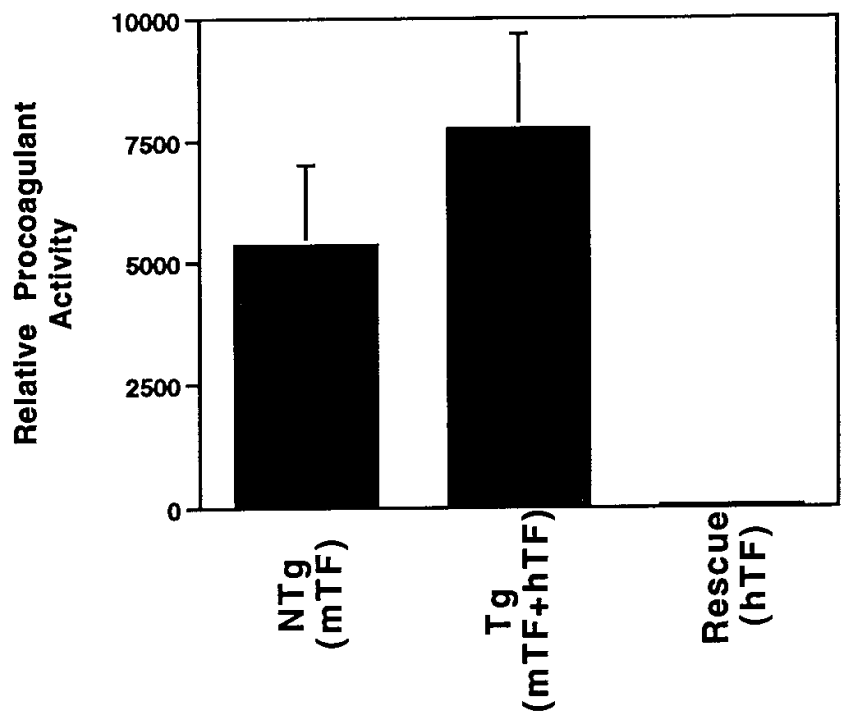

Figure 10. Procoagulant activity of a rescued mouse. Brain extracts were prepared from a nontransgenic $(N T g)$, a transgenic ( $T g$, \#47-51), and a rescued mouse (Rescue, R47-23) and procoagulant activity was determined using a clotting assay with mouse plasma (Sigma Chemical Co.). The clot time (s) was converted to procoagulant activity using a standard curve. Results of triplicate determinations are shown $($ mean $\pm \mathrm{SD})$.

the epidermis of the tongue, perivascular adventitial cells, cardiac myocytes, and brain astrocytes (data not shown). Of note was the pattern of expression in the kidney. Previous studies demonstrated that TF was expressed in glomerular cells in human kidney and tubular cells in the murine kidney (8). In a rescued mouse, hTF was strongly expressed in tubular cells with little or no staining in the glomerular cells. These results indicate that the species-specific pattern of TF expression in the kidney is not due to differences in the regulatory elements in the human and murine TF promoters, but rather is due to the expression of positively acting transcription factors in different cell types in the human and murine kidneys.

We have shown that LPS induction of the human TF gene in monocytic cells in vitro is mediated by a distal enhancer $(-227$ to -172$)$ and requires binding of c-Rel-p65 heterodimers to a $\kappa \mathrm{B}$ site $(28,29)$. This enhancer region is present in the $\mathrm{hTF}$ minigene. Here, we demonstrate that LPS induced nuclear translocation of c-Rel-p65 heterodimers and hTF expression in PECs isolated from transgenic mice in a similar manner to human monocytic cells (29). In addition, LPS induction of the hTF minigene was blocked by the protease inhibitor TPCK (42), suggesting that induction was mediated via an NF-кB/ Rel-dependent mechanism. Future studies will determine the precise role of the -227 to -172 enhancer in LPS induction of the hTF minigene in vivo.

TF expression during murine and human development suggested that TF may play a role in embryogenesis (8). Indeed, targeted disruption of the murine TF gene results in embryonic lethality between days E9.5 and 10.5 (9-11). Our previous studies using a $129 / \mathrm{Sv} \times \mathrm{C} 57 \mathrm{BL} / 6$ background indicated that only one $\mathrm{mTF}^{-/-}$pup of 350 offspring $(0.3 \%)$ survived to birth and then died of hemorrhage (11). More recently, it was reported that $2 \mathrm{mTF}^{-/-}$pups of 108 offspring (1.9\%) survived to birth in the same $129 / \mathrm{Sv} \times \mathrm{C} 57 \mathrm{BL} / 6$ background, whereas no
$\mathrm{mTF}^{-/-}$embryos survived beyond day E10.5 in a $129 / \mathrm{Sv}$ background, suggesting that genetic background can influence the survival of $\mathrm{mTF}^{-1-}$ pups (48). A single TF null pup was reported to live until $4 \mathrm{wk}$ of age, although this mouse was delivered by cesarean section (48). In our study, "rescued" mice were defined as mice that had been vaginally delivered and survive until weaning ( $3 \mathrm{wk}$ ). The genetic background of the offspring analyzed in this study is a mixture of C57BL/ $6[62.5 \%], 129 / \mathrm{Sv}[25 \%]$, and BALB/c[12.5\%]. To date, screening of 117 pups has not detected any $\mathrm{mTF}^{-/-}$pups that lack the hTF minigene, suggesting that it is unlikely that our genetic background significantly contributes to the survival of $\mathrm{mTF}^{-1-}$, $\mathrm{hTF}^{+}$pups observed in this study. Moreover, the rescue rate of $14 \%$ is consistent with the expected rate of $20 \%$. In a second breeding strategy, we observed a rescue rate of $55 \%$ compared with the expected rate of $50 \%$. Taken together, these data strongly suggest that expression of hTF during embryogenesis rescues $\mathrm{TF}^{-1-}$ embryos. At present, hTF expression levels in the visceral yolk sac have not been determined but we speculate, based on the levels of hTF in adult mice, that only low levels of TF are required for rescue. The role of TF in embryogenesis is controversial. Death of embryos has been attributed to fatal hemorrhage (10) or an abnormal yolk sac vasculature (11). We are currently attempting to distinguish between these two possibilities and to determine the role of TF in embryogenesis by rescuing $\mathrm{mTF}^{-/-}$embryos using modified versions of the hTF minigene.

Rescued mice $\left(\mathrm{mTF}^{-/-}, \mathrm{hTF}^{+}\right)$containing only low levels of human TF developed normally with no signs of a bleeding diathesis even after tail transection for genotyping. The procoagulant activity of brain extracts of a rescued mouse was $0.7 \%$ of the level of a wild-type mouse. Low levels of total TF activity of a tissue may not reflect the level of TF activity at critical cell type-specific sites that are required for hemostasis. However, if total TF activity does indeed reflect a low cell typespecific activity of TF at these sites, the viability of these mice suggests that, in the absence of additional challenge, low levels $(<1 \%)$ of TF can maintain hemostasis compatible with normal growth and development. Rescued mice have survived normally up to 7 mo of age with no reduction in viability. This result is consistent with the lack of bleeding observed in experimental animals receiving large doses of inhibitory anti-TF antibodies $(19,20)$. A notable exception to the otherwise normal hemostasis observed in rescued mice was the uterine hemorrhage during pregnancy and subsequent death of four rescued females. Although there are no reports of humans lacking TF, we speculate that the human population may contain individuals either with low total TF or that express low levels of TF in the uterus during pregnancy that may be prone to excessive uterine bleeding.

\section{Acknowledgments}

We would like to acknowledge M. Smith and H. McClary for excellent technical assistance, Dr. K. Kono for advice on quantitative RTPCR, Dr. W. Ruf and Dr. M. Ginsburg for stimulating discussions, Dr. L. Curtis and Dr. M. O'Connell for critical reading of the manuscript, and J. Robertson for preparing the manuscript.

This research was supported by National Institutes of Health grants HL-48872 and HL-16411 (N. Mackman) and was performed during the tenure of an Established Investigatorship from the American Heart Association (N. Mackman) and a Don and Lorraine Jaquot 
Travelling Fellowship from the Royal Australasian College of Physicians (J.H. Erlich).

\section{References}

1. Bach, R.R. 1988. Initiation of coagulation by tissue factor. Crit. Rev. Biochem. 23:339-368.

2. Edgington, T.S., N. Mackman, K. Brand, and W. Ruf. 1991. The structural biology of expression and function of tissue factor. Thromb. Haemost. 66: 67-79.

3. Contrino, J., G. Hair, D.L. Kreutzer, and F.R. Rickles. 1996. In situ detection of tissue factor in vascular endothelial cells: correlation with the malignant phenotype of human breast disease. Nat. Med. 2:209-215.

4. Zhang, Y., Y. Deng, T. Luther, M. Müller, R. Ziegler, R. Waldherr, D.M. Stern, and P.P. Nawroth. 1994. Tissue factor controls the balance of angiogenic and antiangiogenic properties of tumor cells in mice. J. Clin. Invest. 94:13201327.

5. Mueller, B.M., R.A. Reisfeld, T.S. Edgington, and W. Ruf. 1992. Expression of tissue factor by melanoma cells promotes efficient hematogenous metastasis. Proc. Natl. Acad. Sci. USA. 89:1-6.

6. Bromberg, M.E., W.H. Konigsberg, J.F. Madison, A. Pawashe, and A. Garen. 1995. Tissue factor promotes melanoma metastasis by a pathway independent of blood coagulation. Proc. Natl. Acad. Sci. USA. 92:8205-8209.

7. Soifer, S.J., K.G. Peters, J. O'Keefe, and S.R. Coughlin. 1994. Disparate temporal expression of the prothrombin and thrombin receptor genes during mouse development. Am. J. Pathol. 144:60-69.

8. Luther, T., C. Flössel, N. Mackman, A. Bierhaus, M. Kasper, S. Albrecht, E.H. Sage, L. Iruela-Arispe, H. Grossmann, A. Ströhlein, et al. 1996. Tissue factor expression during human and mouse development. Am. J. Pathol. 149:101-113.

9. Toomey, J.R., K.E. Kratzer, N.M. Lasky, J.J. Stanton, and G.J. Broze, Jr. 1996. Targeted disruption of the murine tissue factor gene results in embryonic lethality. Blood. 88:1583-1587.

10. Bugge, T.H., Q. Xiao, K.W. Kombrinck, M.J. Flick, K. Holmback, M.J.S. Danton, M.C. Colbert, D.P. Witte, K. Fujikawa, E.W. Davie, and J.L. Degen. 1996. Fatal embryonic bleeding events in mice lacking tissue factor, the cell-associated initiator of blood coagulation. Proc. Natl. Acad. Sci. USA. 93: 6258-6263.

11. Carmeliet, P., N. Mackman, L. Moons, T. Luther, P. Gressens, I. Van Vlaenderen, H. Demunck, M. Kasper, G. Breier, P. Evrard, et al. 1996. Role of tissue factor in embryonic blood vessel development. Nature. 383:73-75.

12. Fleck, R.A., L.V.M. Rao, S.I. Rapaport, and N. Varki. 1990. Localization of human tissue factor antigen by immunostaining with monospecific, polyclonal anti-human tissue factor antibody. Thromb. Res. 57:765-781.

13. Drake, T.A., J.H. Morrissey, and T.S. Edgington. 1989. Selective cellular expression of tissue factor in human tissues. Am. J. Pathol. 134:1087-1097.

14. Osterud, B., and T. Flæstad. 1983. Increased tissue thromboplastin activity in monocytes of patients with meningococcal infection: related to an unfavorable prognosis. Thromb. Haemost. 49:5-7.

15. Edwards, R.L., F.R. Rickles, and M. Cronlund. 1981. Abnormalities of blood coagulation in patients with cancer. J. Lab. Clin. Med. 98:917-928.

16. Leatham, E., P. Bath, J. Tooze, and A. Camm. 1995. Increased monocyte tissue factor expression in coronary disease. Br. Heart J. 73:10-13.

17. Drake, T.A., J. Cheng, A. Chang, and F.B. Taylor, Jr. 1993. Expression of tissue factor, thrombomodulin, and E-selectin in baboons with lethal Escherichia coli sepsis. Am. J. Pathol. 142:1-13.

18. Morrissey, J.H., and T.A. Drake. 1993. Procoagulant response of the endothelium and monocytes. In Pathophysiology of Shock, Sepsis and Organ Failure. G. Schlag and H. Redl, editors. Springer-Verlag, Berlin. 564-574.

19. Levi, M., H. ten Cate, K.A. Bauer, T. van der Poll, T.S. Edgington, H.R. Büller, S.J.H. van Deventer, C.E. Hack, J. Wouter ten Cate, and R.D. Rosenberg. 1994. Inhibition of endotoxin-induced activation of coagulation and fibrinolysis by pentoxifylline or by a monoclonal anti-tissue factor antibody in chimpanzees. J. Clin. Invest. 93:114-120.

20. Taylor, F.B., Jr., A. Chang, W. Ruf, J.H. Morrissey, L. Hinshaw, R. Catlett, K. Blick, and T.S. Edgington. 1991. Lethal E. coli septic shock is prevented by blocking tissue factor with monoclonal antibody. Circ. Shock. 33: $127-134$.

21. Wilcox, J.N., K.M. Smith, S.M. Schwartz, and D. Gordon. 1989. Localization of tissue factor in the normal vessel wall and in the atherosclerotic plaque. Proc. Natl. Acad. Sci. USA. 86:2839-2843.

22. Moreno, P.R., V.H. Bernardi, J. López-Cuéllar, A.M. Murcia, I.F. Palacios, H.K. Gold, R. Mehran, S.K. Sharma, Y. Nemerson, V. Fuster, and J.T. Fallon. 1996. Macrophages, smooth muscle cells, and tissue factor in unstable angina. Implications for cell-mediated thrombogenicity in acute coronary syndromes. Circulation. 94:3090-3097.

23. Marmur, J.D., M. Rossikhina, A. Guha, B. Fyfe, V. Friedrich, M. Mendlowitz, Y. Nemerson, and M.B. Taubman. 1993. Tissue factor is rapidly induced in arterial smooth muscle after balloon injury. J. Clin. Invest. 91:2253-2259.

24. Golino, P., M. Ragni, P. Cirillo, V.E. Avvedimento, A. Feliciello, N. Esposito, A. Scognamiglio, B. Trimarco, G. Iaccarino, M. Condorelli, et al. 1996. Effects of tissue factor induced by oxygen free radicals on coronary flow during reperfusion. Nat. Med. 2:35-40.

25. Ragni, M., P. Cirillo, I. Pascucci, A. Scognamiglio, D. D'Andrea, N. Eramo, M.D. Ezekowitz, A.B. Pawashe, M. Chiariello, and P. Golino. 1996. Monoclonal antibody against tissue factor shortens tissue plasminogen activator lysis time and prevents reocclusion in a rabbit model of carotid artery thrombosis. Circulation. 93:1913-1918.

26. Jang, I.-K., H.K. Gold, R.C. Leinbach, J.T. Fallon, D. Collen, and J.N. Wilcox. 1992. Antithrombotic effect of a monoclonal antibody against tissue factor in a rabbit model of platelet-mediated arterial thrombosis. Arterioscler. Thromb. 12:948-954.

27. Mackman, N. 1995. Regulation of the tissue factor gene. FASEB (Fed. Am. Soc. Exp. Biol.) J. 9:883-889.

28. Mackman, N., K. Brand, and T.S. Edgington. 1991. Lipopolysaccharidemediated transcriptional activation of the human tissue factor gene in THP-1 monocytic cells requires both activator protein 1 and nuclear factor $\kappa \mathrm{B}$ binding sites. J. Exp. Med. 174:1517-1526.

29. Oeth, P.A., G.C.N. Parry, C. Kunsch, P. Nantermet, C.A. Rosen, and N Mackman. 1994. Lipopolysaccharide induction of tissue factor gene expression in monocytic cells is mediated by binding of c-Rel/p65 heterodimers to a $\mathrm{kB}$ like site. Mol. Cell. Biol. 14:3772-3781.

30. Parry, G.C., and N. Mackman. 1995. Transcriptional regulation of tissue factor expression in human endothelial cells. Arterioscler. Thromb. 15:612-621.

31. Bierhaus, A., Y. Zhang, Y. Deng, N. Mackman, P. Quehenberger, M. Haase, T. Luther, M. Müller, H. Böhrer, J. Greten, et al. 1995. Mechanism of the tumor necrosis factor $\alpha$-mediated induction of endothelial tissue factor. $J$. Biol. Chem. 270:26419-26432.

32. Moll, T., M. Czyz, H. Holzmuller, R. Hofer-Warbinek, E. Wagner, H. Winkler, F.D. Bach, and E. Hofer. 1995. Regulation of the tissue factor promoter in endothelial cells. J. Biol. Chem. 270:3849-3857.

33. Taby, O., C.-L. Rosenfield, V. Bogdanov, Y. Nemerson, and M.B. Taubman. 1996. Cloning of the rat tissue factor cDNA and promoter: identification of a serum-response region. Thromb. Haemost. 76:697-702.

34. Mackman, N., J.H. Morrissey, B. Fowler, and T.S. Edgington. 1989. Complete sequence of the human tissue factor gene, a highly regulated cellular receptor that initiates the coagulation protease cascade. Biochemistry. 28:1755-1762.

35. Mackman, N., S. Imes, W.H. Maske, B. Taylor, A.J. Lusis, and T.A Drake. 1992. Structure of the murine tissue factor gene: chromosome location and conservation of regulatory elements in the promoter. Arterioscler. Thromb. 12:474-483.

36. Morrissey, J.H., H. Fakhrai, and T.S. Edgington. 1987. Molecular cloning of the cDNA for tissue factor, the cellular receptor for the initiation of the coagulation protease cascade. Cell. 50:129-135.

37. Morrissey, J.H., S.A. Gregory, N. Mackman, and T.S. Edgington. 1989 Tissue factor regulation and gene organization. Oxf. Surv. Eukaryotic Genes. 6: 67-84.

38. Stuhlmeier, K.M., V. Csizmadia, Q. Cheng, H. Winkler, and F.H. Bach 1994. Selective inhibition of E-selectin, ICAM-1, and VCAM in endothelial cells. Eur. J. Immunol. 24:2186-2190.

39. Prud'Homme, G.J., D.H. Kono, and A.N. Theofilopoulos. 1995. Quantitative polymerase chain reaction analysis reveals marked overexpression of interleukin-1 $\beta$, interleukin-10 and interferon-gamma mRNA in the lymph nodes of lupus-prone mice. Mol. Immunol. 32:495-503.

40. Morrissey, J.H., D.S. Fair, and T.S. Edgington. 1988. Monoclonal antibody analysis of purified and cell-associated tissue factor. Thromb. Res. 52:247-261.

41. Fang, C.H., T.C. Lin, A. Guha, Y. Nemerson, and W.H. Konigsberg. 1996. Activation of factor X by factor VIIa complexed with human-mouse tissue factor chimeras requires human exon 3. Thromb. Haemost. 76:361-368.

42. Mackman, N. 1994. Protease inhibitors block lipopolysaccharide induction of tissue factor gene expression in human monocytic cells by preventing activation of c-Rel/p65 heterodimers. J. Biol. Chem. 269:26363-26367.

43. Drake, T.A., J.H. Morrissey, and T.S. Edgington. 1989. Selective cellular expression of tissue factor in human tissues. Implications for disorders of hemostasis and thrombosis. Am. J. Pathol. 134:1087-1097.

44. Schlaeger, T.M., S. Bartunkova, J.A. Lawitts, G. Teichmann, W. Risau, U. Deutsch, and T.N. Sato. 1997. Uniform vascular-endothelial-cell-specific gene expression in both embryonic and adult transgenic mice. Proc. Natl. Acad. Sci. USA. 94:3058-3063.

45. Franklin, G.C., M. Donovan, G.I.R. Adam, L. Holmgren, S. PfeiferOhlsson, and R. Ohlsson. 1991. Expression of the human PDGF-B gene is regulated by both positively and negatively acting cell type-specific regulatory elements located in the first intron. EMBO (Eur. Mol. Biol. Organ.) J. 10:13651373 .

46. Eddleston, M., J.C. de la Torre, M.B.A. Oldstone, D.J. Loskutoff, T.S. Edgington, and N. Mackman. 1993. Astrocytes are the primary source of tissue factor in the murine central nervous system. A role for astrocytes in cerebral hemostasis. J. Clin. Invest. 92:349-358.

47. Mackman, N., M.S. Sawdey, M.R. Keeton, and D.J. Loskutoff. 1993. Murine tissue factor gene expression in vivo: tissue and cell specificity and regulation by lipopolysaccharide. Am. J. Pathol. 143:76-84.

48. Toomey, J.R., K.E. Kratzer, N.M. Lasky, and G.J. Broze, Jr. 1997. Effect of tissue factor deficiency on mouse and tumor development. Proc. Natl. Acad. Sci. USA. 94:6922-6926. 